\title{
Ecophysiological role of Embothrium coccineum, a Proteaceae species bearing cluster roots, increasing phosphorus availability in its rhizosphere
}

\author{
M. Delgado ${ }^{1,2}$, A. Zúñiga-Feest ${ }^{2}, F$. Borie $^{1 *}$ \\ ${ }^{1}$ Center of Amelioration and Sustainability of Volcanic Soil. BIOREN-UFRO, Temuco, Chile. \\ ${ }^{2}$ Laboratorio de Biología Vegetal, Instituto de Ciencias Ambientales y Evolutivas, Facultad de Ciencias, \\ Universidad Austral de Chile., Valdivia, Chile. *Correspondingauthor:fernando.borie@ufrontera.cl
}

\begin{abstract}
Native forests in southern South America are constantly subjected to natural disasters such as volcanic eruptions. Soil affected by volcanic ash contain large amounts of total P but low P availability, as this element is strongly adsorbed to soil colloids (i.e. allophane). This lack of available $\mathrm{P}$ is one of the main limitations to plant growth. In this context, it is necessary an in-deep study of plant species that have developed some root physiological strategies for $\mathrm{P}$ acquisition. An example of this is the formation of cluster roots by Proteaceae species. Recently, information has been reported that aids to our understanding of the functioning of Proteaceae species growing in volcanic soils.

The aim of this review is to discuss the ecophysiological role of Proteaceae species growing in young volcanic soils, with a special emphasis on Embothrium coccineum, a pioneer species of extremely disturbed environments. In summary, we reveal here that E. coccineum has several features that make it suitable for recovering degraded soils in south-central Chile. Some of these characteristics include its ability to survive and successfully establish in poor soils due to its specialized roots adaptation and its ability to shed its leaves under stressful conditions. According to recent evidence, E. coccineum has relatively low foliar nutrient resorption leaving at least half of the nutrients in its senescent leaves; this, in turn, promotes nutrient cycling via mineralization of its leaves. Finally, we conclude that the cluster roots of E. coccineum promote P solubilization and mineralization in the rhizosphere soil allowing for increased $\mathrm{P}$ availability for the plant itself and potentially also for neighbouring species.
\end{abstract}

Keywords: Southern South American Proteaceae, cluster roots, phosphorus, volcanic soils 


\section{Introduction}

Temperate rain forests in southern South America contain a wide array of endemic species, which are constantly subjected to disturbance regimes such as volcanic eruptions and earthquakes (Godoy et al., 2009). The soils where these species grow vary widely; however, native forests grow mainly on soils of volcanic origin. Volcanic soils are characterized by high amount of organic matter, low $\mathrm{pH}$, high aluminum (Al) content, and high concentrations of total phosphorus $(\mathrm{P})$ though with low $\mathrm{P}$ availability. These soils often have a low $\mathrm{P}$ availability because this element is strongly adsorbed to soil colloids; a lack of $\mathrm{P}$ is one of the main limitations of plant establishment and growth (Borie and Zunino, 1983; Borie et al., 1989). For this reason, it appears important to study native plants that have developed root physiological strategies for $\mathrm{P}$ acquisition. An example of this includes nonmycorrhizal species, which form cluster (or proteoid) roots, which are ephemeral clusters (persist for a few weeks) of fine rootlets surrounding a main axis (Lamont, 2003; Purnell, 1960). These roots occur in most species belonging to the Proteaceae, but similar root structures also occur in species of other families (Lambers et al., 2006; Lamont, 2003; Louis et al., 1991). The mechanisms of these specialized roots for $\mathrm{P}$ acquisition are well known, including that they can exude large amounts of carboxylates like citrate and malate which promote organic $(\mathrm{Po})$ and inorganic phosphate $(\mathrm{Pi})$ mobilization from the soil's particles bound P. In addition, these roots can also exude significant levels of phosphatases, which hydrolyze organic $\mathrm{P}$.

Many Proteaceae species are renowned for their capacity to thrive on some of the world's most ancient and phosphorus- (P) impoverished soils (Lambers et al., 2013a; Lambers et al. 2010). However, there is little information available on the root ecophysiology of Proteaceae species growing in young, frequently disturbed and more fertile landscapes (Delgado et al., 2014; Delgado et al., 2013; Donoso-Ñanculao et al., 2010; Piper et al., 2013; Ramírez et al., 1990; Ramírez et al., 2005; Zúñiga-Feest et al., 2010) and most of the studies that have been conducted are on the single species, Embothrium coccineum (J.R. Forst $\&$ G. Forst). This species grows in volcanic soils characterized by high total $\mathrm{P}$ content $(>1500 \mathrm{mg} \mathrm{kg}$ $\left.{ }^{1}\right)$, but due to the high reactivity of this element with soil colloids, total $\mathrm{P}$ availability is low for plants. The aim of this review is to discuss the role of cluster roots and other adaptive advantages of a Proteaceae species growing in young volcanic soils. Herein, we discuss on Embothrium coccineum as a pioneer species of extremely disturbed environments.

\section{Cluster Roots}

Cluster roots have mainly been studied in Australia and South Africa, where the main centers of Proteaceae diversity are found (Barker et al., 2007; Pate et al., 2001). The soils on which these species have evolved are considered among the most nutrientpoor in the world (Lambers et al., 2010; Lambers et al., 2008). Lambers et al. (2010) highlight the high diversity of plant species with specialized roots (mainly Proteaceae) inhabiting ancient and highly weathered soils such as those found in South Western Australia. In contrast, species with these specialized nutrient-acquisition strategies are very uncommon in soils with greater $\mathrm{P}$ content. In addition, Lambers et al. (2008) suggest that the mining strategy ("from root of nutrient-solubilising or hydrolysing exudates") dominates in ancient soils, where most $\mathrm{P}$ is absorbed in soil particles, while the scavenging strategy of 
mycorrhizal symbioses is common in younger soils, where the $\mathrm{P}$ concentration in the soil solution is greater. However, in the case of southern Chile, where the soils are young, it is also possible to find species with specialized cluster roots.

In Chile and Argentina, there are six species of the Proteaceae family all of which have cluster roots (Gonzalez, 1990): Embothrium coccineum, Gevuina avellana (Mol), Lomatia dentata (Ruiz et Pavón) R. Br., Orites myrtoidea (Poepp. \& Endl.) Benth.\& Hook. F. ex B. D. Jacks., Lomatia ferruginea (Cav.) R. Br., Lomatia hirsuta (Lam.) Diels. ex Macbr. Some morphological characteristics of cluster roots in four South American Proteaceae seedlings (seven-monthsold) can be observed in Figure 1. It is important to note that cluster sizes vary within species but overall, cluster roots of G. avellana are larger than any other Proteaceae species and can reach sizes of up to $9 \mathrm{~cm}$ long in adult individuals (Ramírez et al., 2005).

To date, there is little information available about the functioning of cluster roots of Proteaceae species growing in young volcanic soils, though some studies have been conducted, most of them using the species E. coccineum. Delgado et al. (2014) found that $E$. coccineum has small cluster roots, which release large amounts of carboxylates under P deficiency. This phenomenon has been shown to occur mainly when cluster roots have stopped growing in the mature developmental stage (Figure 2b), which for $E$. coccineum is 13 to 25 days after emergence. The release of these organic compounds found in $E$. coccieum is relatively fast in comparison to Hakea prostrata Br., a southwestern Australian species (Delgado et al., 2014). The authors suggested that this difference is probably due to the mineralogical characteristics of the soil. This means that, Chilean Proteaceae, endemic to volcanic soils absorbing high amounts of $\mathrm{P}$, exude more carboxylates from small cluster roots because they can mobilize substantially more P. In contrast, the Australian Proteaceae, which grows in extremely $\mathrm{P}$ poor soil, has relatively slow carboxylate-exudation rates but explores a large volume of soil through its large cluster roots. These findings provide some evidence for the existence of a trade-off between cluster root biomass and carboxylate exudation rate as shown in E. coccineum and $H$. prostrata when grown under similar conditions. However, further research is needed to fully answer the following questions: $i$ ) what occurs in other species bearing cluster roots?; do cluster roots with less biomass exude carboxylates at faster rates than cluster roots with greater biomass?; ii) does carboxylate exudation depend on the mineralogical characteristics of the soil?. These questions provide new opportunities to continue studying these issues in future research.

According to field observations (Delgado unpublished data), the maximum size of cluster roots in adult plants of E. coccineum and G. avellana are 5 and 8 $\mathrm{cm}$ long, respectively, on average. Similar sizes have been found in 54 representative seedlings of the South African Proteaceae, where the sizes of individual clusters range from 0.2 to $7.5 \mathrm{~cm}$ long and 0.1 to 3.4 $\mathrm{cm}$ wide (Lamont, 1982). Also it has been found that the size of cluster roots in 10-month old seedlings of Hakea species (Australian Proteaceae) ranged from 6.6 to $13.0 \mathrm{~cm}$ long. However, in adult plants of Hakea prostrata, the cluster roots reached approximately 20 $\mathrm{cm}$ long and $7 \mathrm{~cm}$ wide (Lamont, 1972).

As mentioned above, G. avellana has the largest cluster roots of the southern South American Proteaceae. As shown in Figure 2 (a, b), G. avellana's cluster roots grow in a grape bunch-like formation adhering large amounts of soil to its rootlets even when they are dry (Figure $2 \mathrm{c}, \mathrm{d}$ ).

Besides regarding their size, it is important to mention the large surface area of cluster roots. In addition to the fine rootlets arranged in longitudinal rows (five in the 
case of E. coccineum, Figure 3a) that form the cluster, there are many root hairs growing on the rootlets (Figure 3c). In Leucadendron laureolum, the surface area can be up to 140 times greater in comparison to non-cluster roots (Lamont, 2003). While the surface area of cluster roots of E. coccineum has not yet been determined, in Figure $3 \mathrm{c}$ we can observe a large number of root hairs that have developed on the surface of the rootlets exceeding many times that found in non-cluster roots (Figure 3d).

\section{Ecological importance of Embothrium coccineum, a pioneer species from southern South America}

Embothrium coccineum is an endemic species from southern South America, which has a wide geographical distribution (from $35^{\circ} \mathrm{S}$ to $56^{\circ} \mathrm{S}$ in Chile and $39^{\circ} \mathrm{S}$ to $55^{\circ} \mathrm{S}$ in Argentina). It is one of the most widely distributed species of temperate forests, covering c. $20^{\circ}$ in its latitudinal distribution (Souto and Premoli, 2007). In addition to its extensive north to south distribution, which extends for approx. $2200 \mathrm{~km}$, E. coccineum can also be found at a variety of altitudes from sea level to 1200 m.a.s.l in the Andes Mountains. Because of this, it has been named as a species with high plasticity; it is possible to find E. coccineum as a tree (up to $15 \mathrm{~m}$ tall), as a shrub, or as a stunted tree (ca. $0.5 \mathrm{~m}$ tall) in its highest altitudinal range (Figure $4 \mathrm{~b}, \mathrm{c}$ ). This indicates both the morphological and genetic variation of this species along with its climatic and edaphic distribution (Souto and Premoli, 2007; Souto et al., 2009; Souto and Smouse, 2013).

Because E. coccineum is a successful pioneer species following catastrophic events such as landslides, fire, clear-cutting, or massive tree fall, it is a valuable resource for the establishment and recovery of degraded natural forests (Rovere and Chalcoff, 2010; Souto and Smouse, 2013). The colonizing ability of $E$. coccineum is most likely attributed to its high annual seed production, high germination rate, fast growth in comparison to other native species, high resprouting ability, and of course, due to its cluster root formation (Escobar et al., 2006). Although southern South American Proteaceae do not accumulate as much P in seeds as Proteaecae species from South Western Australia and South Africa (Table 1), E. coccineum has a high capacity to establish in extremely poor soil (Figure 4a), such as in young rocky soil in Patagonia (Zúñiga-Feest et al., 2014). This is possible because this species forms cluster roots when the plant is a small seedling ( $\sim$ one month-old), even before it has shed its cotyledons (Figure 5), which probably allows it to extract $\mathrm{P}$ from the soil at very early life stages.

In addition to $\mathrm{P}$ solubilization and mineralization through the release of large amounts of carboxylates and phosphatases by cluster roots (Lambers et. al., 2006), some authors have shown that these root structures (in Hakea actities, Proteaceae), contribute to organic $\mathrm{N}$ acquisition through a higher expression of putative amino acids and peptide transporters (Schmidt et al., 2003; Paungfoo-Lonhienne et al., 2009). In this sense, Piper et al. (2013) found a negative logarithmic relationship between cluster root number and soil nitrogen $(\mathrm{N})$, suggesting that cluster roots of E. coccineum in small seedlings (< six months-old) could also promote $\mathrm{N}$ acquisition. However, further experimental research is needed to evaluate the generality of this statement.

E. coccineum is a shade intolerant species that behaves as a facilitator for other species requiring protection from direct light. In addition, this species has been considered resistant to extreme conditions such as drought and low temperatures being able to shed its leaves under unfavorable conditions (Escobar et al., 2006; Rovere and Chalcoff, 2010; Steubing et al., 1983). This characteristic of leaf shedding not only can occur during unfavorable weather conditions, but also when the plant is exposed to an excess of soil 
nutrients. For example, Delgado et al. (2014) observed that six month-old seedlings shed their leaves to avoid $\mathrm{P}$ toxicity when grown under high-P conditions (250 $\mu \mathrm{M} \mathrm{P}$ in solution). In this sense, it should be noted that many Proteaceae inhabiting soils of South Western Australia and southern Africa are sensitive to $\mathrm{P}$ toxicity even at slight increases in $\mathrm{P}$ concentration in the soil solution. Several studies have shown that this is because some of these species have a low capacity to down-regulate their P-uptake systems (de Campos et al., 2013; Hawkins et al., 2008; Shane et al., 2004). However, Delgado et al. (2014) found that $E$. coccinuem grown in a high $\mathrm{P}$ concentration solution has a high capacity to down-regulate its P-uptake systems. We do not know whether all Proteaceae species growing in volcanic soils have the capacity to down regulate P-uptake. According to another study (Ávila, 2014), O. myrtoidea, an endemic shrub from Chile and Argentina, does not function in the same way as E. coccineum. Ávila (2014) evaluated the survival of E. coccinuem and O. myrtoidea growing in soil with contrasting $\mathrm{P}$ availability and found that E. coccineum showed a $100 \%$ survival rate in both volcanic $\left(\mathrm{P} \mathrm{Olsen}=1.26 \mathrm{mg} \mathrm{kg}^{-1}\right)$ and organic soils $(\mathrm{P}$ Olsen $\left.=17.3 \mathrm{mg} \mathrm{kg}^{-1}\right)$, whereas $O$. myrtoidea showed low survival in organic soil (27\%) compared with volcanic soil (100\%). The suggested cause of seedling death due to $\mathrm{P}$ toxicity was that the $O$. myrtoidea seedlings had a low capacity to down-regulate their P-uptake system. However, this requires further assessment, as differences in P sensitivity depend on the species and the soil characteristics as well as their geographical origins.

The residence time of leaves on the tree also depends on the given species of Proteaceae. For example, the leaf lifespan of G. avellana, L. ferruginea and L. hirsuta are 4.9, 2.9 and 2.3 years respectively, while leaves of E. coccineum only have a lifespan of 0.8 years (Lusk and Corcuera, 2011). This short leaf residence time on the tree and the ability of E. coccineum to shed leaves under stressful conditions have great ecological importance for E. coccineum for two main reasons. First, shedding leaves allows E. coccineum to evade stressful conditions and then to generate new leaves that maintain the vitality of the plant. Second, when E. coccineum sheds its leaves, it increases the nutrient input to the soil thereby providing nutrient sources for itself and other plants. In this sense, Lambers et al. (2012) reported that Chilean Proteaceae remobilize low P from senescent to mature leaves, suggesting that these species act as "ecosystem engineers" by providing P to the soil via leaf litter deposition.

Recently, Fajardo and Piper (2015) refute this hypothesis stating that: "E. coccineum proves not to be an ecosystem engineer." They found that this species showed a higher $\mathrm{P}$ and $\mathrm{N}$ resorption efficiency compared with neighboring species in Chilean Patagonia. Despite these results found in this study, it is interesting to note that the $\mathrm{N}$ and $\mathrm{P}$ concentration in mature leaves of $E$. coccineum was higher than in most species evaluated and $\mathrm{N}$ and $\mathrm{P}$ resorption from senescent to mature leaves was less than $50 \%$. These results imply that, although E. coccineum is more efficient in foliar nutrient resorption than neighboring species, it still provides nutrients to the soil because senescent leaves maintain at least half of their nutrients ( $\mathrm{N}$ and $\mathrm{P}$ ) and also because the leaf life span is shorter than that of other evergreen species (Lusk and Contreras, 1999). Thus, overall more leaf litter is incorporated in the soil.

Results obtained in our laboratory related to the $\mathrm{P}$ and $\mathrm{N}$ resorption efficiency of three Proteaceae species growing in their natural habitat are shown in Table 2. In general, we found low nutrient resorption efficiency, particularly apparent for $G$. avellana and $L$. ferruginea while $E$. coccineum showed the highest efficiency in $\mathrm{P}$ and $\mathrm{N}$ resorption. Most likely, these percentages of nutrient resorption differ among species and over the 
geographic and edaphic distribution. In relation to the latter, Hayes et al., (2014) reported that foliar P and $\mathrm{N}$ concentrations and reabsorption efficiency in plants differ according to the nutrient availability in the soil. Lambers et al. (2013) suggest that low foliar nutrient resorption efficiency is of great ecological importance in volcanic soils with high $\mathrm{P}$ retention, because the input of nutrients to the soil could facilitate the establishment of species without specialized roots. While recent studies have provided information concerning this matter, the fact that Proteaceae species grow in a wide range of climatic and edaphic conditions suggests that there is a need to study how these species reabsorb nutrients in a more global context along its wide geographic distribution.

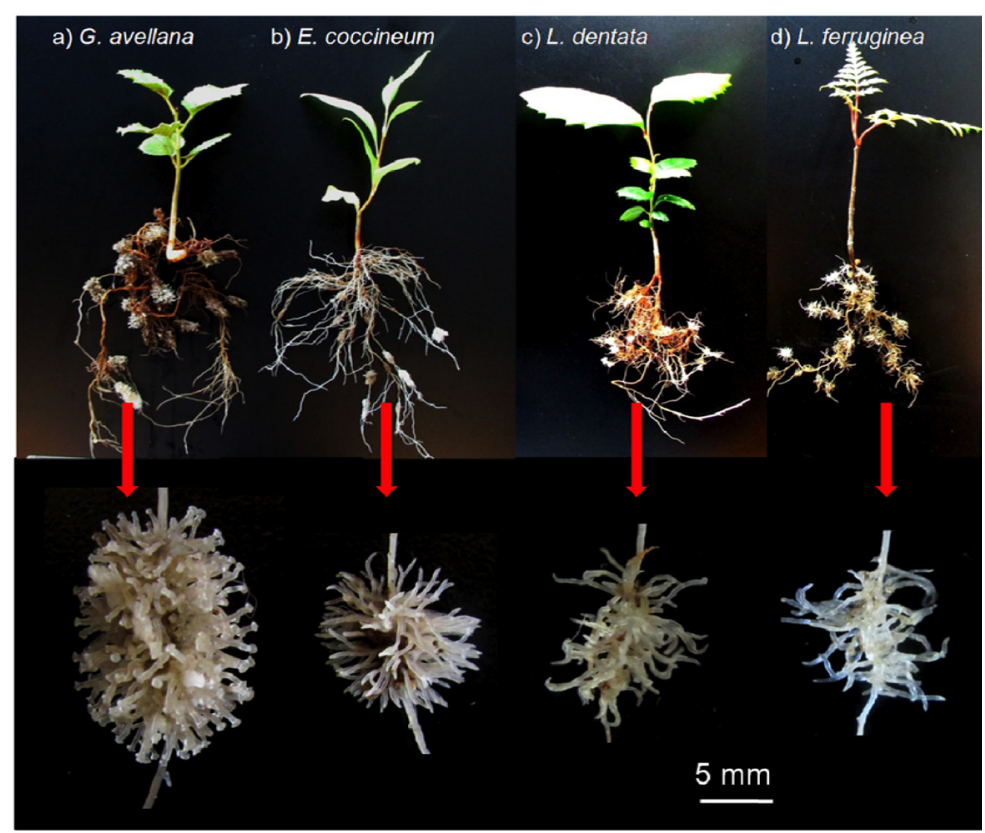

Figure 1. Cluster roots of a) Gevuina avellana, b) Embothrium coccineum and c) Lomatia dentata seedlings growing in a mixed substrate of sand and perlite (2:1). d) Cluster roots of a Lomatia ferruginea seedling growing in volcanic soils (pumicite).

\section{Cluster roots of $E$. coccineum modify their rhi- zosphere and increase $p$ availability}

In general, soils in southern Chile are derived from volcanic ash, which have low levels of available P. There is low $\mathrm{P}$ availability due to the high adsorption capacity of oxides/hydroxides of $\mathrm{Fe}$ and $\mathrm{Al}$ and due to the fact that over $50 \%$ of $\mathrm{P}$ is associated with organic matter (Borie and Rubio, 2003; Vistoso et al., 2012). As a consequence of low levels of available P, spe- cies bearing cluster roots release organic compounds allowing them to solubilize and mineralize insoluble phosphates. Recent studies of the southern South American Proteaceae show that cluster roots modify $P$ availability in the rhizosphere depending on the soil type and the development stage of cluster roots. Ávila (2014) showed that seedlings of E. coccineum grown in volcanic soil $\left(\mathrm{P}\right.$ Olsen $\left.=1.26 \mathrm{mg} \mathrm{kg}^{-1}\right)$ had lower relative growth rates but higher cluster root formation and exudation of phosphatases and carboxlylates than 
seedlings grown in organic soil ( $\mathrm{P}$ Olsen $=17.3 \mathrm{mg} \mathrm{kg}$ $\left.{ }^{1}\right)$. In this study, E coccineum was compared with $O$. myrtoidea, and it was found that both species growing in volcanic soil (low P availability) significantly increased $\mathrm{P}$ availability in the rhizosphere compared with non-rhizosphere soil. For E. coccineum, P availability in the rhizosphere increased by $50 \%$ and for O. myrtoidea it increased by $120 \%$. These results agree with those presented by Delgado (2014) who found that cluster roots of E. coccineum modified the lability of different $\mathrm{P}$ fractions in the rhizosphere, increasing significantly the moderately labile inorganic $P$ fraction in the rhizosphere of mature cluster roots than in the other rhizosphere soils evaluated (corresponding to rhizosphere of juvenile, semi-senescent, senescent and non-cluster roots).

Delgado (2014) found the highest total P concentration in the roots at the mature stage, suggesting that the fastest P-uptake occurs at this developmental stage.
In addition, Delgado (2014) described that E. coccineum biologically modifies the rhizosphere of its cluster roots depending on their development stage. Rhizosphere from mature cluster roots had the lowest values of enzymatic activity of both plant and microbial origins (phosphatase, $\beta$-glucosidase, dehydrogenase and the rate of hydrolysis of fluorescein diacetate) compared to the rhizosphere soil of other cluster root developmental stages. A similar trend was observed by Weisskopf et al. (2006), who found that exuding cluster roots of Lupinus albus L. use several mechanisms to reduce microbial growth on the rhizosphere. These authors state that "acidification against bacteria and excretion of isoflavonoids as well as cell wall-degrading enzymes against fungi" reduce microbial degradation of citric acid exuded from the plant's cluster roots and consumption of solubilized $\mathrm{P}$, allowing this nutrient to be more available for plant uptake.
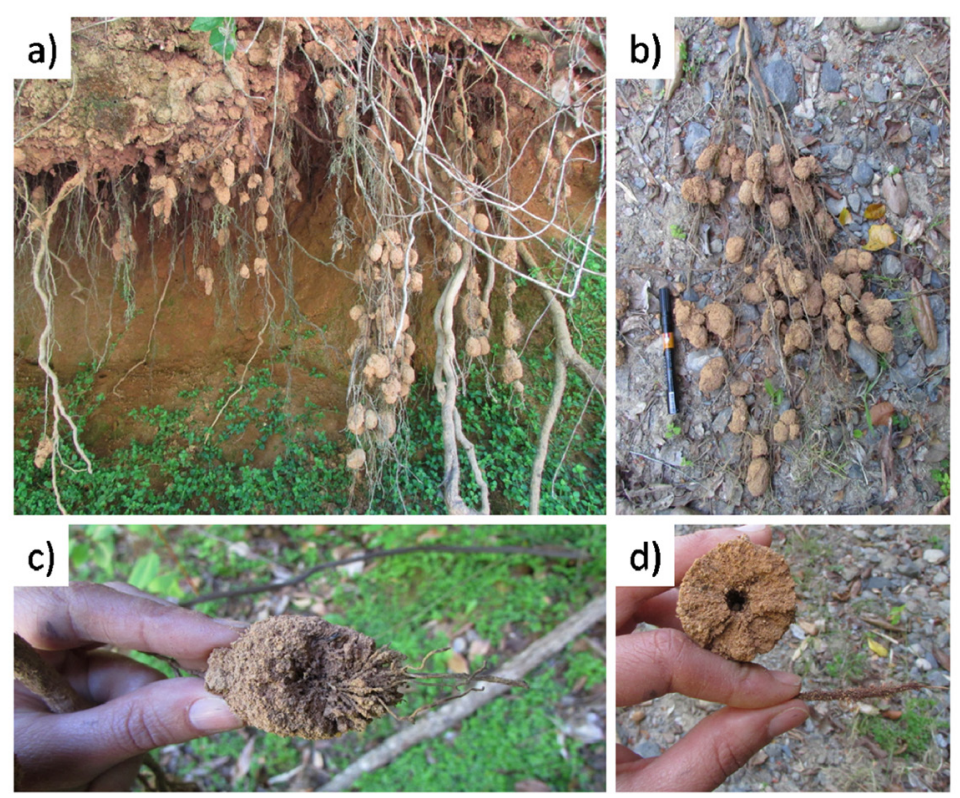

Figure 2. a) Cluster roots of Gevuina avellana hanging beside a road near Nahuelbuta National Park, b) bunch of cluster roots, c) and d) dried roots showing soil adhered to the rootlets. 


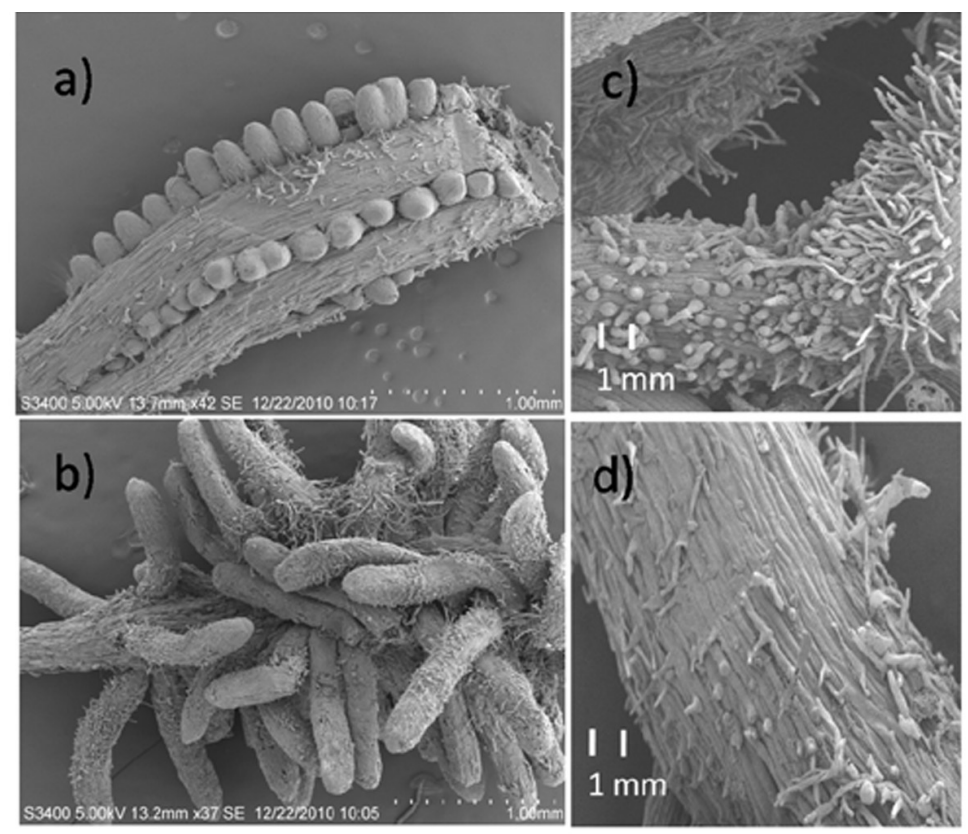

Figure 3. Electron microscopy of cluster roots of Embothrium coccineum showing a) the initiation of cluster roots, b) the mature stage, c) rootlets with many developed root hairs on their surfaces and d) non-cluster roots.

The ability of some species to chemically mobilize nutrients such as $\mathrm{P}$ in the soil could have a great and unexpected importance. This mobilization through the release of organic compounds (acid phosphatases, carboxylates) by roots increases inorganic $\mathrm{P}$ in the soil solution, making it available for the plant itself and eventually for neighboring non-P-mobilizing species. Li et al. (2014) hypothesize that nutrient mobilization (e.g. P, Mn, Fe and $\mathrm{Zn}$ ) by some species plays an important role in facilitative interactions enhancing productivity in both natural ecosystems and biodiversity experiments. In this sense, Muler et al. (2014) evaluated whether or not a non-cluster root bearing species, Scholtzia involucrate, could benefit from the nutrient mobilization ( $\mathrm{P}$ or micronutrients) by co-occurring with Banksia attenuate, a species bearing cluster roots. These authors found that $B$. attenuata facilitates Mn uptake and growth of $S$. involucrate, most likely because cluster roots increase the availability of $\mathrm{Mn}$ and $\mathrm{P}$ in the soil, making it more available for the neighboring plants.
In our laboratory we evaluated the possible positive interaction between Sophora microphylla (a legume tree that is associated with symbiotic $\mathrm{N}_{2-}$ fixing bacteria) and E. coccineum. Our results showed that $S$. microphylla increased the number of $\mathrm{N}_{2-}$ fixing nodules when accompanied by E. coccineum, though there was no significant change in the soil N. On the other hand, E. coccineum growing along with S. microphylla promoted an increase of $\mathrm{P}$ availability in volcanic soils, especially in the rhizosphere zone. However, changes in the relative growth rates of both species, growing alone or in association, were not observed. These results do not support the positive interaction hypothesis, perhaps because the duration of the experiment (6 months) was not enough to observe significant changes in growth. We suggest continuing with these types of experiments over the long term as facilitation between species has potential use in increasing productivity in co-occurring species, thus protecting biodiversity in degraded natural ecosystems. 

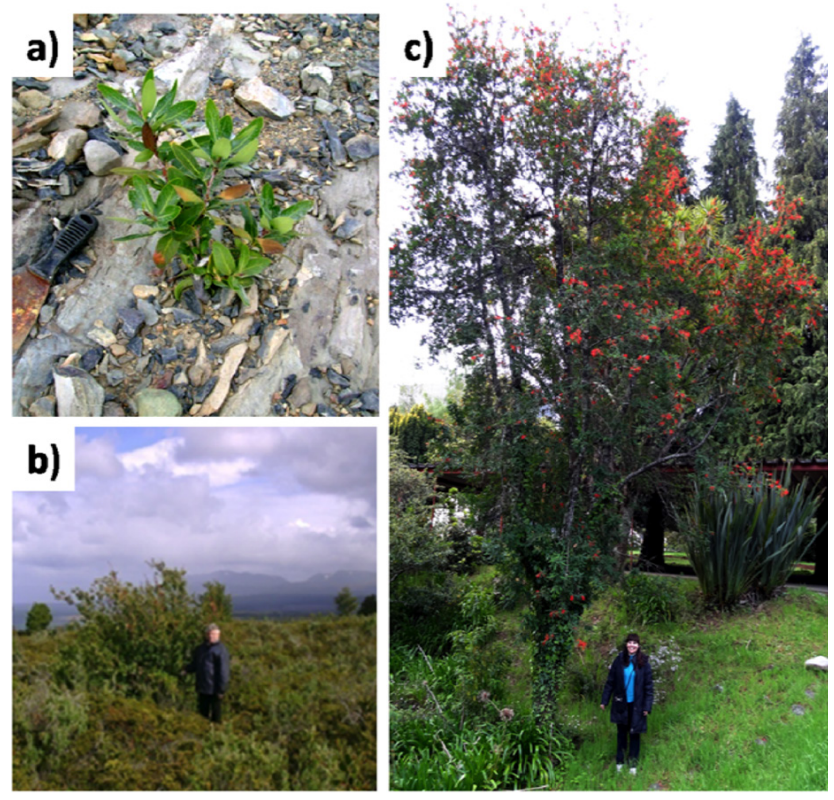

Figure 4. Embothrium coccineum growing in different conditions a) seedlings growing on rocky young soil, b) a shrub growing in the southern part of its distribution (Chilean Patagonia) and c) a tree (up to $8 \mathrm{~m}$ tall) growing in the central part of its distribution (Valdivia).

Table. 1 Comparison of seed phosphorus (P) concentration and seed dry mass among South Western (SW) Australian, Southern African and South American Proteaceae species

\begin{tabular}{lrcc}
\hline \multicolumn{1}{c}{ Average } & $\begin{array}{c}\text { seed }[\mathbf{P}] \\
\left(\mathrm{mg} \mathrm{g}^{-1}\right)\end{array}$ & $\begin{array}{c}\text { seed mass } \\
(\mathbf{m g ~ D W})\end{array}$ & Reference \\
\hline 41 SW Australian Proteaceae & $13.2 \pm 0.8$ & $85.5 \pm 23.3$ & Groom and Lamont (2010) \\
25 Southern African Proteaceae & $5.8 \pm 0.8$ & $53.4 \pm 11.2$ & Groom and Lamont (2010). \\
6 southern South & $3.2 \pm 0.4$ & $11.5 \pm 1.4$ & Delgado et al., (2014) \\
American Proteaceae & & & \\
\hline
\end{tabular}




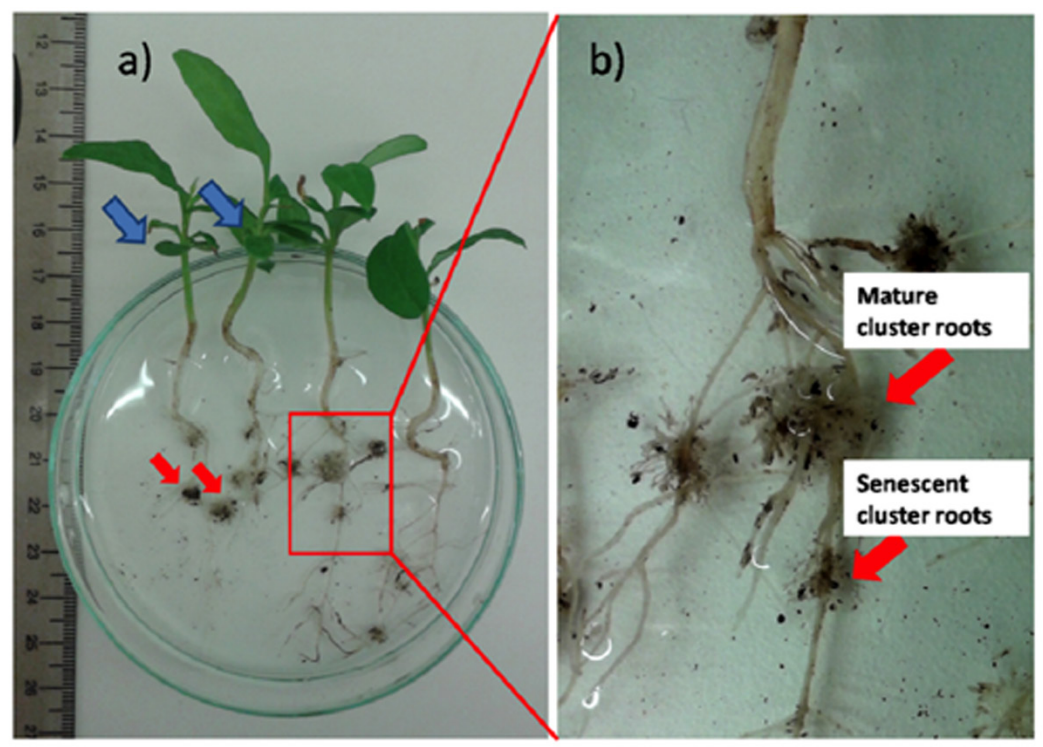

Figure 5. a) Two month-old seedlings of Embothrium coccineum showing cotyledons (blue arrows) and cluster roots (red arrows), b) root system of E. coccineum showing mature and senescent cluster roots.

\section{Concluding remarks and future directions}

As discussed in this review, E. coccineum has several features that make it suitable for colonizing young volcanic soils of south-central Chile since it can survive and establish successfully in poor soils due to its low nutritional requirements and high thermal tolerance (e.g. low temperatures). In addition, E. coccineum has the potential to accelerate nutrient cycling through the mineralization of it senescent leaves that have a relatively high nutrient content and are shedded more frequently than those of other evergreen species. Also, we described how cluster roots chemically and biochemically modify their rhizosphere thereby increasing $\mathrm{P}$ availability in the soil. Nevertheless, physical properties such as soil aggregation, aggregate stability, porosity, etc., still require further study, using long-term trials, as these are key factors to control erosion in areas that are highly vulnerable to this process.

The knowledge of these aspects allows us to increase our understanding on the auto-ecology of Proteaceae species and the role that they play in their environments. Because of this, we propose that these species could potentially aide for the recovery of degraded soils (P deficient, eroded) and should be used in reforestation or in intercropping systems.

In this way, Proteaceae could facilitate $\mathrm{P}$ acquisition in species lacking these root adaptations and eventually could enhance the productivity of neighboring species and thereby could reduce the use/cost of phosphate fertilizer. 
Table 2. Phosphorus $(\mathrm{P})$ and nitrogen $(\mathrm{N})$ concentration in mature and senescent leaves, and the respective nutrient resorption efficiency of three South American Proteaceae species growing in their natural habitat* in Puyehue National Park. Each value represents the mean and standard error in parentheses, $n=3$.

\begin{tabular}{|c|c|c|c|}
\hline & \multicolumn{2}{|c|}{$P$ concentration $\left(\mathrm{mg} \mathrm{g}^{-1}\right)$} & \multirow{2}{*}{$\begin{array}{c}\text { P resorption efficiency } \\
(\%)\end{array}$} \\
\hline & Mature Leaf & Senescent Leaf & \\
\hline E. coccineum & $0.36(0.05)$ & $0.20(0.01)$ & $44.0(5.8)$ \\
\hline G. avellana & $0.25(0.01)$ & $0.23(0.02)$ & $8.1(3.7)$ \\
\hline \multirow[t]{3}{*}{ L. ferruginea } & $0.25(0.02)$ & $0.22(0.01)$ & $8.9(1.7)$ \\
\hline & \multicolumn{2}{|c|}{$\mathrm{N}$ concentration $\left(\mathrm{mg} \mathrm{g}^{-1}\right)$} & \\
\hline & Mature Leaf & Senescent Leaf & $\begin{array}{c}\mathrm{N} \text { resorption efficiency } \\
(\%)\end{array}$ \\
\hline E. coccineum & $17.9(1.3)$ & $6.3(0.6)$ & $64.7(2.4)$ \\
\hline G. avellana & $14.5(2.2)$ & $9.15(0.1)$ & $32.3(10.1)$ \\
\hline L. ferruginea & $11.5(0.9)$ & $5.6(0.2)$ & $49.8 \quad(5.9)$ \\
\hline
\end{tabular}

*The available $\mathrm{P}$ and $\mathrm{N}$ in soil was on average $12.42 \mathrm{mg} \mathrm{Kg}^{-1}$ and $19.6 \mathrm{mg} \mathrm{Kg}^{-1}$, respectively

\section{Acknowledgements}

Postdoctoral research grant Fondecyt N`3150187 MD, Fondecyt regular 1130440 AZF

\section{References}

Ávila A. 2014. Evaluación de la capacidad de extracción de fósforo en Proteáceas Chilenas. Master Thesis. Universidad Austral de Chile, Valdivia, Chile, $72 \mathrm{p}$.

Barker, N.P., Weston, P.H., Rutschmann, F., Sauquet, H. 2007. Molecular dating of the 'Gondwanan' plant family Proteaceae is only partially congruent with the timing of the break-up of Gondwana. J. Biogeogr. 34, 2012-2027.
Borie, F., Rubio, R. 2003. Total and organic phosphorus in Chilean volcanic soils. Gayana Bot. 60, 69-73.

Borie, F., Zunino, H., Martínez, L. 1989. Macromolecule-P associations and inositol phosphates in some chilean volcanic soils of temperate regions. Commun. Soil Sci.Plant Anal. 20, 1881-1894.

Borie, F., Zunino, H. 1983. Organic matter-phosphorus associations as a sink in p-fixation processes in allophanic soils of Chile. Soil Biol.Biochem. 15, 599-603.

de Campos, M.C.R., Pearse, S.J., Oliveira, R.S., Lambers, H. 2013. Down-regulation of net phosphorus uptake capacity is inversely related to leaf phosphorus resorption in four species from a phosphorus-impoverished environment. Ann. Bot. 111, 445-454. 
Delgado, M., Zúñiga-Feest, A., Alvear, M., Borie, F. 2013. The effect of phosphorus on cluster-root formation and functioning of Embothrium coccineum (R. et J. Forst.). Plant Soil 373, 765-773.

Delgado, M., Suriyagoda, L., Zúñiga-Feest, A., Borie, F., Lambers, H. 2014. Divergent functioning of Proteaceae species: the South American Embothrium coccineum displays a combination of adaptive traits to survive in high-phosphorus soils. Funct. Ecol. 28, 1356-1366.

Delgado, M. 2014. Formation, functioning and effect on the rhizosphere of cluster roots of a South American Proteaceae: Embothrium coccineum. Doctoral Thesis. Universidad de la Frontera, Temuco, Chile. 107 p.

Donoso-Ñanculao, G., Castro, M., Navarrete, D., Bravo, L.A., Corcuera, L.J. 2010. Seasonal induction of cluster roots in Embothrium coccineum J.R. Forst. \& G. Forst. in the field: factors that regulate their development. Chil. J. Agr. Res. 70, 559-566.

Escobar, E., Donoso, C., Souto, C., Alberdi, M., Zúñiga, A. 2006. Embothrium coccineum J.R. et. G. Foster. In: Donoso, C. (ed). Las Especies Arbóreas de los Bosques Templados de Chile y Argentina. Autoecología Marisa Cúneo, Valdivia, Chile. pp: 233-245.

Fajardo, A. and Piper, F.I. 2015. High foliar nutrient concentrations and resorption efficiency in Embothrium coccineum (Proteaceae) in Southern Chile. Am. J. Bot. 102, 1 - 9.

Godoy R., Paulino, L., Valenzuela, E., Oyarzún, C., Huygens, D., Boeckx, P. 2009. Temperate ecosystems of Chile: characteristic biogeochemical cycles and disturbance regimes. In: Verhoest, N., Boeckx P., Oyarzún, C., Godoy, R (eds). Ecological advances on Chilean temperate rainforests. Belgium. Academia Press, pp: 31-40.

Gonzalez, M. 1990. Estudio comparativo de las raíces de las Proteaceas Chilenas cultivadas en el jardín botánico de la Universidad Austral de Chile. Tesis Ing. Forestal, Universidad Austral de Chile, Valdivia, $72 \mathrm{p}$.

Groom, P.K., Lamont, B.B. 2010. Phosphorus accumulation in Proteaceae seeds: a synthesis. Plant Soil. 334, 61-72.

Hawkins, H.-J., Hettasch, H., Mesjasz-Przybylowicz, J., Przybylowicz, W., Cramer, M.D. 2008. Phosphorus toxicity in the Proteaceae: a problem in post-agricultural lands. Sci. Hort. 117, 357-365.

Hayes, P., Turner, B.L., Lambers, H., Laliberté, E. 2014. Foliar nutrient concentrations and resorption efficiency in plants of contrasting nutrientacquisition strategies along a 2-million-year dune chronosequence. J. Ecol. 102, 396-410

Lambers, H., Ahmedi, I., Berkowitz, O., Dunne, C., Finnegan, P.M., Hardy, G.E.S.J., Jost, R., Laliberté, E., Pearse, S.J., Teste, F.P. 2013a. Phosphorus nutrition of phosphorus-sensitive Australian native plants: threats to plant communities in a global biodiversity hotspot. Conserv. Physiol. 1, $1-21$.

Lambers, H., Bishop, J.G., Hopper, S.D., Laliberté, E., Zúñiga-Feest, A. 2012a. Phosphorus-mobilization ecosystem engineering: the roles of cluster roots and carboxylate exudation in young Plimited ecosystems. Ann. Bot. 110, 329-348.

Lambers, H., Brundrett, M.C., Raven, J.A., Hopper, S.D. 2010. Plant mineral nutrition in ancient landscapes: high plant species diversity on infertile soils is linked to functional diversity for nutritional strategies. Plant Soil. 334, 11-31.

Lambers, H., Clements, J.C., Nelson, M.N. 2013 b. How a phosphorus-acquisition strategy based on carboxylate exudation powers the success and agronomic potential of lupines (Lupinus, Fabaceae). Am. J. Bot. 100, 1-26 
Lambers, H., Raven, J.A., Shaver, G.R., Smith, S.E. 2008. Plant nutrient-acquisition strategies change with soil age. Trends Ecol. Evol. 23, 95-103.

Lambers, H., Shane, M.W., Cramer, M.D., Pearse, S.J., Veneklaas, E.J. 2006. Root structure and functioning for efficient acquisition of phosphorus: matching morphological and physiological traits. Ann. Bot. 98, 693-713.

Lamont, B.B. 2003. Structure, ecology and physiology of root clusters - a review. Plant Soil. 248, 1-19.

Lamont, B.B. 1982. Mechanisms for enhancing nutrient uptake in plants, with particular reference to Mediterranean south Africa and western Australia. Bot. Rev. 48, 597-689.

Lamont, B.B. 1973. Factors affecting the distribution of proteoid root within the root systems of two Hakea species. Aust. J. Bot. 21,165-187.

Lamont, B.B. 1972. The morphology and anatomy of proteoid roots in the genus Hakea. Aust. J. Bot. $20,155-74$

Li, L., Tilman, D., Lambers, H. Zhang, Fu-Suo. 2014. Plant diversity and overyielding: insights from belowground facilitation of intercropping in agriculture. New Phytol. 203, 63-69

Louis, I., Racette, S., Torrey, J.G. 1991. The occurrence of cluster roots in actinorhizal plants. In: D.L. Kiester, P. B. Cregan (eds). The Rhizosphere and Plant Growth. Kluwer Academic Publishers, Dordrecht. pp:119.

Lusk, C.H., Corcuera, L.J. 2011. Effects of light availability and growth rate on leaf lifespan of four temperate rainforest Proteaceae. Rev. Chi. Hist. Nat. 84, 269-277

Lusk, C.H., Contreras O. 1999. Foliage area and crown nitrogen turnover in temperate rain forest juvenile trees of differing shade tolerance. J. Ecol. $87,973-983$
Muler, A. L., Oliveira, R.S., Lambers, H., Veneklaas, E.J. 2014. Does cluster-root activity benefit nutrient uptake and growth of co-existing species? Oecologia. 174, 23-31

Pate, J.S., Verboom, W.H., Galloway, P.D. 2001. Cooccurrence of Proteaceae, laterite and related oligotrophic soils: coincidental associations or causative inter-relationships?. Aust. J. Bot. 49, 529-560.

Piper, F., Baeza, G., Zúñiga-Feest, A., Fajardo, A. 2013. Soil nitrogen, and not phosphorus, promotes cluster-root formation in a South American Proteaceae, Embothrium coccineum. Am. J. Bot. 100, 2328-2338

Paungfoo-Lonhienne, C., Schenk, P. M., Lonhienne, T. G., Brackin, R., Meier, S., Rentsch, D., Schmidt, S. 2009 . Nitrogen affects cluster root formation and expression of putative peptide transporters. J. Exp. Bot. 60, $2665-2676$.

Purnell, H. 1960. Studies of the family Proteaceae. I. Anatomy and morphology of the roots of some Victorian species. Aust. J. Bot. 8, 38-50.

Ramírez, C., Grinbergs, J., Valenzuela, J., San Martin, C. 1990. Influencia de las raíces proteiformes en plántulas de Gevuina avellana Mol. Bosque. 11, $11-20$

Ramírez, C., Valenzuela, E., San Martín, C. 2005. Nuevos antecedentes sobre desarrollo temprano, morfología y anatomía de las raíces proteiformes de Gevuina avellana. Agro Sur. 32, 33-44

Rovere, A. E., Chalcoff, V. R. 2010. Embothrium coccineum J. R. Forst. et G. Forst. Kurtziana. 35, 2333.

Schmidt, S., Mason, M., Sangtiean, T., Stewart, G.R. 2003. Do cluster roots of Hakea actities (Proteaceae) acquire complex organic nitrogen?. Plant Soil. 248: 157-165 
Shane, M.W., Szota, C., Lambers, H. 2004. A root trait accounting for the extreme phosphorus sensitivity of Hakea prostrata (Proteaceae). Plant Cell Environ. 27, 991-1004.

Souto, C.P., Premoli, A.C. 2007. Genetic variation in the widespread Embothrium coccineum (Proteaceae) endemic to Patagonia: effects of phylogeny and historical events. Aust. J. Bot. 55, 809-817

Souto, C.P., Premoli, A.C., Reich, P.B. 2009. Complex bioclimatic and soil gradients shape leaf trait variation in Embothrium coccineum (Proteaceae) among austral forests in Patagonia. Rev. Chi. Hist. Nat. 82, 209-222.

Souto, C.P., Smouse, P. E. 2013. Correlated morphological and genetic patterns in Embothrium coccineum (Proteaceae) across climate and geography: can Embothrium survive patagonian climate change? Aust. J. Bot. 61, 516-527

Steubing, L., Alberdi, M., Wenzel, H. 1983. Seasonal changes of cold resistance of Proteaceae of the South Chilean laurel forest. Vegetatio. 52, 35-44.

Suriyagoda, L.D.B., Lambers, H., Renton, M. , Ryan, M.H. 2012. Growth, carboxylate exudates and nutrient dynamics in three herbaceous perennial plant species under low, moderate and high phosphorus supply. Plant Soil. 358, 105-117.
Vistoso, E., Theng, B.K.G., Bolan, N.S., Parfitt, R.L., Mora M.L. 2012. Competitive sorption of molybdate and phosphate in Andisols. J. Soil Sci. Plant Nutr. 12, 59-72

Weisskopf, L., Abou-Mansour, E., Fromin, N., Tomasi, N., Santelia, D., Edelkott, I., Neumann, G., Aragno, M., Tabacchi, R., Martinoia, E. 2006. White lupin has developed a complex strategy to limit microbial degradation of secreted citrate required for phosphate acquisition. Plant Cell Environ. 29, 919-927.

Zúñiga-Feest, A., Delgado, M. \& Alberdi, M. 2010. The effect of phosphorus on growth and clus ter-root formation in the Chilean Proteaceae: Embothrium coccineum (R. et J. Forst.). Plant Soil. 334, 113-121.

Zúñiga-Feest, A., Delgado, M., Bustos, A. 2014. Chapter 16: Cluster roots. In: Asunción Morte and Ajit Varma (Eds). Root Engineering: Basic and Applied Concepts. Berlin, Heidelbergh,pp: 353-367 